\section{PRAKTISCH COMPENDIUM GEEN MUST HAVE VOOR AIOS}

\section{R. Snijders, V. Smit. Compendium Geneeskunde. Rotterdam: Synopsis BV, 2017. 1162 pagina's. ISBN 978-90-825709-0-8. Prijs € 129,95.}

Werd je er niet mee geconfronteerd in de basisopleiding, dan wel in de huisartsenopleiding: de voortgangstoets. Twee studenten zagen een gat in de markt en ontwikkelden samen met nog eens 56 geneeskundestudenten en 38 specialisten een compendium dat claimt het volledige curriculum van de basisopleiding te omvatten. Dat compendium is handig en praktisch, maar mist ook diepgang.

In vier handzame, mooi vormgegeven delen zijn de hoofdstukken onderverdeeld naar discipline. Ieder hoofdstuk is op eenzelfde, overzichtelijke manier opgebouwd, waarbij informatie beknopt, puntsgewijs en in tabelvorm wordt weergegeven. Dit maakt het boek minder geschikt voor verdieping, maar het is ideaal om op een pragmatische en doelgerichte wijze aan relevante informatie te komen. Uitermate handig om je voor te bereiden op een kennistoets. Praktisch in de spreekkamer zijn de kaders met typische klachtenpresentaties, die je bij vrijwel iedere diagnose terugvindt.

Het boek is diagnosegericht geschreven. Hierdoor vind je snel beknopte informatie over een waarschijnlijkheidsdiagnose, maar is een onverklaarbaar symptoom moeilijker binnen een diagnose te passen. Daarnaast is de kracht van het boek ook de grootste valkuil. Om het volledige curriculum in een handzaam boek te krijgen, is er ingeleverd op diepgang. Hierdoor mist het voor praktische toepasbaarheid vaak net de
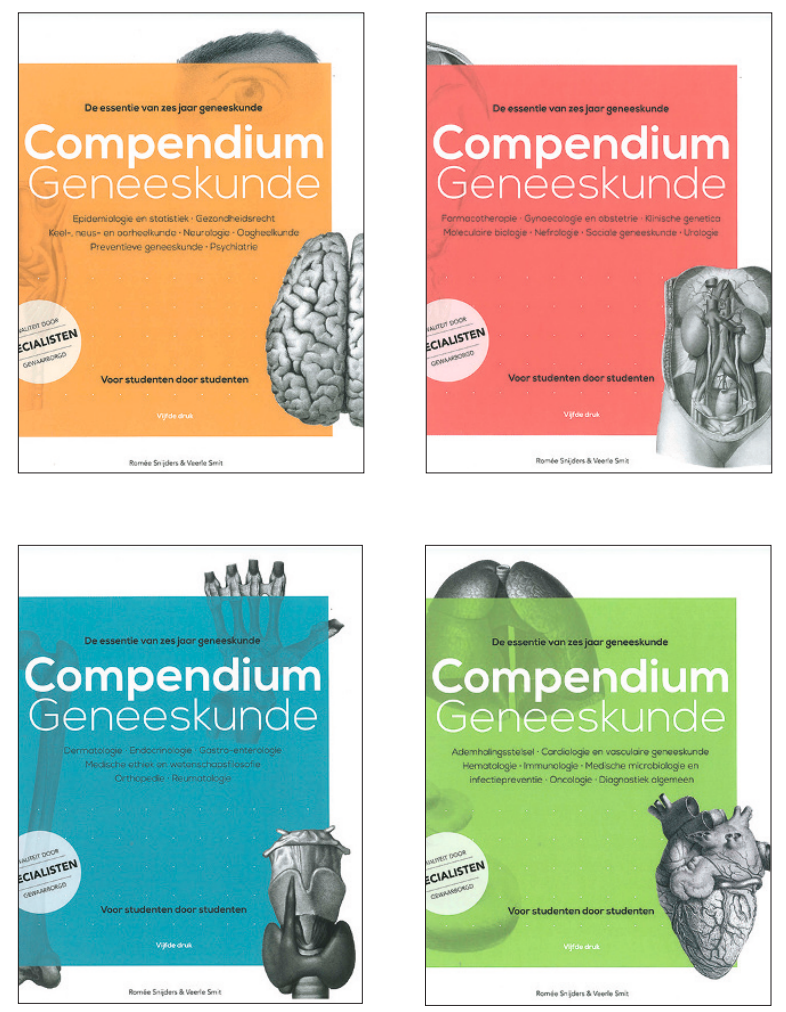

essentie. Het compendium is prima voor de aios die op zoek is naar een naslagwerk met generalistische basiskennis. Voor diepgaander informatie die praktisch toepasbaar is, kan hij beter een specialistischer naslagwerk kiezen dat is gericht op de eerste lijn.

Eveline Kool, Niels Snellen, Iris Berghuis

\section{WAARDERING:}

\section{COLOFON}

Huisarts en Wetenschap wordt uitgegeven door het Nederlands Huisartsen Genootschap [NHG], de wetenschappelijke vereniging van huisartsen. www.henw.org.

\section{Redactie}

Ivo Smeele [hoofdredacteur], Marian van den Brink, Ben Crul, Marianne Dees, Mirrian Hilbink, Sjoerd Hobma, Victor van der Meer, Nadine Rasenberg, Annet Sollie, Wim Verstappen.

\section{Redactiesecretariaat}

Henny Helsloot [secretaresse], Judith Mulder [web- en eindredactie], Susan Umans [bladmanagement], Anita Wittebol [office manager], Steven de Kock, Marjolein Oosterom, Wouter Scheen [eindredactie], Margot

Scheerder, Wendy Westerhof [beeldredactie].

Postbus 3231, 3502 GE Utrecht, tel. 030-2823550, redactie@nhg.org

\section{Uitgever}

Bohn Stafleu van Loghum, Postbus 246, 3990 GA Houten

Basisvormgeving Frederik Helfrich, Deventer

Auteursinformatie: www.henw.org

\section{Advertentieverkoop}

Advertentieverkoop: adverteren@bsl.nl, tel. 030-6383603.

Advertenties behoeven goedkeuring van de redactie.

Inzenden aan: traffic@bsl.nl, tel.030-6383874.

\section{Abonnementen}

H\&W verschijnt 12 keer per jaar en wordt verspreid onder de leden van het NHG. Niet-leden kunnen zich abonneren via www.bsl.nl. Abonnementsprijs: [print + online toegang] € 258,00, Online-only abonnement $€ 154,80$. Studenten 50\% korting.

Abonnementen worden automatisch verlengd tenzij 2 maanden voor de vervaldatum schriftelijk opgezegd. Voorwaarden: www.bsl.nl/ klantenservice/abonnementen

Info: Klantenservice, Postbus 246, 3990 GA Houten, tel. 030-6383736.

\section{Voorwaarden}

Op leveringen en diensten zijn de bij de Kamer van Koophandel gedeponeerde algemene voorwaarden van Springer Media B.V. van toepassing. Zie www.bsl.nl/voorwaarden. 